\title{
Effects of Acid-Base Variables on Ion Transport in Rat Colon
}

\author{
David S. Goldfarb, Richard W. Egnor, and Alan N. Charney \\ Nephrology Section, Veterans Administration Medical Center, New York, New York 10010; and Department of Medicine,
}

New York University School of Medicine, New York, New York 10016

\begin{abstract}
Alterations in arterial acid-base variables have important effects on colonic electrolyte transport in vivo. To confirm the relative effects of these variables and to characterize the transport processes involved, we measured unidirectional ${ }^{22} \mathrm{Na}$ and ${ }^{36} \mathrm{Cl}$ fluxes across short-circuited, distal colonic mucosa of Sprague-Dawley rats. Stripped tissues were studied in Hepes buffer and in Ringer's solutions at $\mathrm{HCO}_{3}$ concentrations of 11, 21, and $39 \mathrm{mM}$, and $\mathrm{CO}_{2}$ tensions between 0 and $69.6 \mathrm{mmHg}$. Increases in $\mathrm{PCO}_{2}$, but not in either $\mathrm{pH}$ or $\mathrm{HCO}_{3}$ concentration, caused similar increases in $J_{\text {net }}^{\mathrm{Na}}$ and $J_{\text {net }}^{\mathrm{C}}$ (net flux of sodium and chloride, respectively) from $-0.2 \pm 0.3$ and $-1.5 \pm 0.4 \mu \mathrm{eq} /$ $\mathrm{cm}^{2}$ per $\mathrm{h}$ at $\mathrm{PCO}_{2}=0$ to $6.8 \pm 0.6$ and $7.6 \pm 0.7 \mu \mathrm{eq} / \mathrm{cm}^{2}$ per $\mathrm{h}$, respectively, at $\mathrm{PCO}_{2}=69.6 \mathrm{mmHg}$. These increases were accounted for by changes in Jms and were accompanied by small decreases in Isc. $1 \mathrm{mM}$ acetazolamide decreased both $J_{\text {met }}^{\mathrm{Na}}$ and $J_{\text {net }}^{\mathrm{Cl}}$ and their responses to increases in $\mathrm{CO}_{2} .0 .75 \mathrm{mM}$ luminal amiloride prevented the increase in sodium absorption, but did not affect the $\mathrm{CO}_{2}$-induced increase in chloride absorption. In the presence of amiloride, $\mathrm{CO}_{2}$ increased $J^{\mathrm{R}}$ (residual flux). $0.1 \mathrm{mM}$ luminal furosemide did not affect the $\mathrm{CO}_{2}$-induced increases in $J_{\text {met }}^{\mathrm{Na}}$ in the absence or presence of amiloride. Changes in $\mathrm{HCO}_{3}$ concentration did not alter $J^{\mathrm{R}}$. We conclude that ambient $\mathrm{CO}_{2}$ effects active, electroneutral sodium absorption in the rat distal colon. The process stimulated by $\mathrm{CO}_{2}$ is dependent on mucosal carbonic anhydrase activity and most likely represents $\mathrm{Na} / \mathrm{H}$ and $\mathrm{Cl} / \mathrm{HCO}_{3}$ ion exchange.
\end{abstract}

\section{Introduction}

The in vivo observation that arterial acid-base variables have a major effect on intestinal electrolyte and water transport suggested a mechanism other than neurohumoral by which the body maintains electrolyte homeostasis (1-3). The distal colon of the rat is of particular interest in this regard, because its electrolyte transport systems are well characterized (4-9), and its response to arterial $\mathrm{PCO}_{2}$ and $\mathrm{HCO}_{3}$ concentration is specific and spans the physiological range of values for these variables. As in other transporting epithelia, the effects of $\mathrm{CO}_{2}$ apparently were mediated through changes in the intracellular

Portions of this work were previously published as abstracts in 1986. Clin. Res. 34:649a (Abstr.), and 1987. Gastroenterology. 92:1407 (Abstr.).

Address reprint requests to Dr. Alan N. Charney, Nephrology Section, Veterans Administration Medical Center, 408 First Avenue, New York, NY 10010.

Received for publication 13 April 1987 and in revised form 30 November 1987.

The Journal of Clinical Investigation, Inc.

Volume 81, June 1988, 1903-1910
$\mathrm{pH}(\mathrm{pHi})^{1}$ of the colonic epithelium $(10,11)$, and were dependent on mucosal carbonic anhydrase activity (12). The data also suggested that the transport processes affected were electroneutral and included both $\mathrm{Na} / \mathrm{H}$ ion exchange and $\mathrm{Cl}$ / $\mathrm{HCO}_{3}$ ion exchange $(3,11,13)$.

Several questions were raised by these findings that could not be addressed in studies of intact animals. These included determining whether $(a)$ the action of $\mathrm{PCO}_{2}$ was entirely a local effect on the colonic epithelium, $(b)$ the electroneutral sodium absorptive process stimulated by $\mathrm{CO}_{2}$ reflected coupled $\mathrm{NaCl}$ cotransport as well as $\mathrm{Na} / \mathrm{H}$ exchange, (c) the effect of the plasma $\mathrm{HCO}_{3}$ concentration on net $\mathrm{HCO}_{3}$ secretion reflected transcellular (as opposed to intercellular) $\mathrm{HCO}_{3}$ movement, and $(d)$ whether the responsive transport processes were $\mathrm{pH}$ sensitive in the absence of ambient $\mathrm{CO}_{2}$.

These issues were addressed in the present study by examining distal colonic tissue in the Ussing (E. W. Wright, Guilford, CT) ion flux chamber. This experimental approach was especially suitable because the response of this tissue to $\mathrm{CO}_{2}$ is immediate, of significant magnitude, and completely reversible $(2,3,11-13)$. As compared with in vivo studies, this method allows for the precise control and manipulation of acid-base variables in the absence of secondary cardiovascular and systemic neurohumoral influences. In addition, we could examine the role of various electrolyte transport processes by comparing the effects of $\mathrm{PCO}_{2}$ in the presence and absence of specific inhibitors of each process.

\section{Methods}

Male Sprague-Dawley rats weighing 250-350 g were maintained on a standard diet with free access to water. While the rats were under pentobarbital sodium anesthesia $(5 \mathrm{mg} / 100 \mathrm{~g}$ body wt), the distal 10 $\mathrm{cm}$ of descending colon was removed, rinsed with $0.9 \%$ saline, and placed over a glass rod. The tissue was stripped of the serosa and segments were mounted in modified Ussing half-chambers (E. W. Wright) exposing $1.12 \mathrm{~cm}^{2}$ surface area. One tissue pair was obtained from each animal.

The transepithelial potential difference (PD) was measured using calomel electrodes connected to the half-chambers by bridges containing 3\% agar constituted in the same Ringer's solution used as bathing solution. The PD was expressed as serosal side positive with respect to the mucosa. Tissues were studied under short-circuited conditions except for 1-s intervals every $100 \mathrm{~s}$, during which bipolar pulses of $0.5 \mathrm{mV}$ yielded electrical current values that were used to calculate tissue conductance (G). The short-circuit current (Isc) was passed across the tissue through 3\% agar bridges via a voltage clamp (University of Iowa, Iowa City, IA). Isc, by convention, was given the same polarity as PD. Tissues were paired for ion flux studies on the basis of differences in $G$ no greater than $25 \%$.

1. Abbreviations used in this paper: DIDS, 4,4'-diisothiocyanostilbene2,2' disulfonate; G, conductance; Isc, short-circuit current; $J_{\mathrm{ms}}^{\mathrm{Cl}}$, mucosal to serosal chloride flux; $J_{\text {net }}^{\mathrm{C}}$, net chloride flux; $J \mathrm{~ms}$, mucosal to serosal flux; $J_{\mathrm{ms}}^{\mathrm{Na}}$, mucosal to serosal sodium flux; $J_{\text {net }}^{\mathrm{Na}}$, net sodium flux; $J$ net, net flux; Jsm, serosal to mucosal flux; PD, potential difference; $\mathrm{pHi}$, intracellular $\mathrm{pH}$. 
Unidirectional fluxes of $\mathrm{Na}$ and $\mathrm{Cl}$ were measured by adding $2 \mu \mathrm{Ci}$ of ${ }^{22} \mathrm{Na}$ and $1 \mu \mathrm{Ci}$ of ${ }^{36} \mathrm{Cl}(100 \mathrm{Ci} / \mathrm{g}$ sp act; New England Nuclear, Boston, MA) to the mucosal side of one member of each tissue pair and the serosal side of the other. After an initial 15-30-min equilibration period, samples of the hot side were collected at the beginning and end of a 45-min experimental period for determination of each isotope's specific activity. Samples of the cold side were taken every $15 \mathrm{~min}$ during the 45-min period for determination of unidirectional ion flux. Samples from both sides were replaced with the appropriate Ringer's solutions. Ready-Solv HP (Beckman Instruments, Inc., Fullerton, CA) was added to each sample and counts were obtained in a liquid scintillation system (LS-3133P) and a gamma counter (both obtained from Beckman Instruments, Inc.). Mucosal to serosal ( $\mathrm{Jms})$ and serosal to mucosal (Jsm) fluxes were calculated by standard formulae (4), and net flux (Jnet) was calculated as the difference between them $(J \mathrm{~ms}-J \mathrm{sm})$. The residual flux $\left(J^{\mathrm{R}}\right)$ was calculated by $J^{\mathrm{R}}=I \mathrm{sc}-\left(J_{\text {net }}^{\mathrm{Na}}-J_{\text {net }}^{\mathrm{Cl}}\right)$.

\section{Acid-base variables}

Paired tissues were bathed in $10 \mathrm{ml}$ of identical Ringer's solutions at $37^{\circ} \mathrm{C}$ containing (in millimoles per liter): $\mathrm{NaCl}, 96 ; \mathrm{NaHCO}_{3}, 21$; $\mathrm{KCl}, 4 ; \mathrm{Na}_{2} \mathrm{HPO}_{4}, 2.4 ; \mathrm{NaH}_{2} \mathrm{PO}_{4}, 0.4 ; \mathrm{Na}$ gluconate, 18; $\mathrm{CaSO}_{4}, 1.0 ;$ $\mathrm{MgSO}_{4}, 1.2$; and glucose, 10. Tissue pairs were studied during two or four consecutive 45-min experimental periods in which bathing solution $\mathrm{HCO}_{3}$ concentration and $\mathrm{pH}, \mathrm{PCO}_{2}$ and $\mathrm{pH}$, or $\mathrm{HCO}_{3}$ concentration and $\mathrm{PCO}_{2}$ were altered. Bicarbonate concentrations were altered by substituting $\mathrm{Na}$ gluconate or Hepes buffer for $\mathrm{NaHCO}_{3}$ over the range 0 to $39 \mathrm{mM}$. In $\mathrm{HCO}_{3}$-free Ringer's solution, Hepes buffer was titrated with $1 \mathrm{M} \mathrm{HCl}$ or $\mathrm{NaOH}$, and the solution was gassed with $100 \% \mathrm{O}_{2}$. In $\mathrm{HCO}_{3}-\mathrm{H}_{2} \mathrm{CO}_{3}$-buffered solutions, tissues were gassed with either room air $\left(\mathrm{PCO}_{2}=0 \mathrm{mmHg}\right), 3 \% \mathrm{CO}_{2} / 97 \% \mathrm{O}_{2}\left(\mathrm{PCO}_{2}=21.9\right.$ $\mathrm{mmHg}$ ), $5 \% \mathrm{CO}_{2} / 95 \% \mathrm{O}_{2}\left(\mathrm{PCO}_{2}=34.5 \mathrm{mmHg}\right)$, or $11 \% \mathrm{CO}_{2} / 89 \% \mathrm{O}_{2}$ $\left(\mathrm{PCO}_{2}=69.6 \mathrm{mmHg}\right)$. In preliminary time-control experiments, stable levels of sodium and chloride flux were observed for more than $6 \mathrm{~h}$, and changes in transport induced by the acid-base variables were fully reversible.

The $\mathrm{pH}$ and $\mathrm{PCO}_{2}$ of the bathing solutions studied in consecutive periods were measured before isotope addition with a Radiometer BMS 3 MK 2 system; with a (PHM 73 acid-base analyzer; London, Cleveland, $\mathrm{OH})$. Bicarbonate concentration was calculated by the Henderson-Hasselbach equation as previously described $(1,2)$. In salt solutions, $p \mathrm{~K}^{\prime}=6.33-0.52(I)^{1 / 2} \pm 0.6(I)$, where 6.33 is the $p \mathrm{~K}$ of the $\mathrm{H}_{2} \mathrm{CO}_{3}-\mathrm{HCO}_{3}$ buffer system in water, and $I$ is the sodium plus potassium concentrations in moles per liter $(2,14)$. To correct $p \mathrm{~K}^{\prime}$ for $\mathrm{pH}$, an empiric factor was determined in this laboratory: $p \mathrm{~K}^{\prime \prime}=p \mathrm{~K}^{\prime}-\log (1$ $\left.+\log ^{\mathrm{pH}-8.7}\right)$. The $\mathrm{CO}_{2}$ solubility in salt solutions was adjusted for ionic strength: alpha $=10^{-1.482-0.085(I)}(2,14)$.

\section{Inhibitors}

We then examined whether inhibitors affected the change in transport caused by the acid-base variables. Electrolyte transport was measured at a bathing solution $\mathrm{HCO}_{3}$ concentration of $21 \mathrm{mM}$ during consecutive periods of $\mathrm{PCO}_{2}=21.6$ and $69.6 \mathrm{mmHg}$ before and after the addition of the specific inhibitor.

Acetazolamide. Sodium acetazolamide (Lederle Parenterals, Inc., Carolina, PR) was added to both mucosal and serosal bathing solutions at a final concentration of 0.1 or $1.0 \mathrm{mM}$. Electrolyte transport was measured at a bathing solution $\mathrm{HCO}_{3}$ concentration of $21 \mathrm{mM}$ during consecutive periods of $\mathrm{PCO}_{2}=21.6$ and $58.6 \mathrm{~mm} \mathrm{Hg}$, and $\mathrm{PCO}_{2}=21.6$ and $69.6 \mathrm{mmHg}$.

Amiloride. Amiloride (Merck Sharp \& Dohme Research Laboratories, West Point, PA) was added to the mucosal bathing solution at a final concentration of $0.75 \mathrm{mM}$. The effect of amiloride also was studied in a bathing solution in which choline chloride was substituted for sodium chloride so as to reduce the sodium concentration to $50 \mathrm{mM}$.

Furosemide. Furosemide (Sigma Chemical Co., St. Louis, MO) was added to the mucosal bathing solution at a final concentration of $0.1 \mathrm{mM}$.
Amiloride and furosemide. To determine whether amiloride and furosemide were additive in their effects and whether the effect of furosemide was affected by the presence of amiloride, $0.75 \mathrm{mM}$ amiloride and $0.1 \mathrm{mM}$ furosemide were both added to the mucosal bathing solution. The effects of increasing $\mathrm{PCO}_{2}$ were then compared with the changes caused by $\mathrm{CO}_{2}$ in the presence of amiloride or furosemide.

4,4'-Diisothiocyanostilbene-2,2' disulfonate (DIDS). DIDS was added to the mucosal side of a $21-\mathrm{mM} \mathrm{HCO} \mathrm{HCO}_{3}$ Ringer's solution at a final concentration of $0.1 \mathrm{mM}$ or $1 \mathrm{mM}$.

\section{Statistics}

Calculated values for the $315-\mathrm{min}$ samples for each condition were averaged and the values for each experimental group were expressed as the mean \pm SE. Statistical analyses consisted of paired and unpaired, two-tailed $t$ tests, one-way analysis of variance, and linear regression analysis by least squares (15). Correlation coefficients were calculated from the mean values of the experimental groups. Corrections were made for multiple $t$ tests when appropriate, and a $2 P$ value $<0.05$ was considered significant.

\section{Results}

\section{Acid-base variables}

The effects of varying the $\mathrm{PCO}_{2}$ on electrolyte transport at a bathing solution $\mathrm{HCO}_{3}$ concentration of $21 \mathrm{mM}$ are shown in Table I. At $\mathrm{PCO}_{2}=0 \mathrm{mmHg}$, net $\mathrm{Na}$ absorption was zero and net chloride secretion was observed. The residual ion flux, $J^{\mathrm{R}}$, also was zero. $\mathrm{Net} \mathrm{Na}$ and $\mathrm{Cl}$ absorption were noted at $\mathrm{PCO}_{2}$ $=21.6 \mathrm{mmHg}$, and progressively increased so that at $\mathrm{PCO}_{2}$ $=69.6 \mathrm{mmHg}$, net $\mathrm{Na}$ and $\mathrm{Cl}$ absorption had increased $\sim 60 \%$. The increase in absorption was accounted for by an increase in $J \mathrm{~ms}$ rather than by a reduction in $J \mathrm{sm}$. Increases in $\mathrm{PCO}_{2}$ between 0 and $69.6 \mathrm{mmHg}$ did not alter PD, but did increase $J^{\mathrm{R}}(P<0.05)$ and decrease the Isc $(P<0.01)$ and conductance $(P<0.02)$. These changes in ion flux and $\mathrm{G}$ were completely reversible, and occurred regardless of the order in which $\mathrm{PCO}_{2}$ was altered.

To determine to what extent the observed responses were effects of $\mathrm{PCO}_{2}$ and not $\mathrm{pH}$, we measured electrolyte fluxes at bathing solution $\mathrm{HCO}_{3}$ concentrations of 39 and $11 \mathrm{mM}$ at a constant $\mathrm{PCO}_{2}$ of $34.5 \mathrm{mmHg}$. As shown in Table II, there were no significant differences in the net absorption of sodium or chloride in these solutions of markedly different $\mathrm{HCO}_{3}$ concentration and $\mathrm{pH}$. Indeed, the $\mathrm{pH}$ range examined in this experiment (7.65-7.14) was similar to that caused by changing $\mathrm{PCO}_{2}$ from 21.6 to $69.6 \mathrm{mmHg}$ (compare Tables I and II). There also was no effect of $\mathrm{pH}$ or $\mathrm{HCO}_{3}$ concentration on $J^{\mathrm{R}}$, although $J^{\mathrm{R}}$ tended to be greater in $39 \mathrm{mM} \mathrm{HCO}_{3}$ than in 11 $\mathrm{mM} \mathrm{HCO}_{3}$ Ringer's solution.

Nevertheless, because these data were obtained (by necessity) in separate groups of tissues, a small effect of $\mathrm{pH}$ may have been obscured by intertissue variability. We therefore measured ion flux in a $\mathbf{H C O}_{3}$-free Hepes-Ringer's solution gassed with $100 \% \mathrm{O}_{2}$ that was titrated during consecutive periods with $\mathrm{HCl}$ or $\mathrm{NaOH}$. As shown in Table II, $J_{\mathrm{ms}}^{\mathrm{Na}}, J_{\mathrm{net}}^{\mathrm{Na}}, J_{\mathrm{ms}}^{\mathrm{C}}$, and $J_{\text {net }}^{\mathrm{Cl}}$ were markedly reduced in the virtual absence of ambient $\mathrm{HCO}_{3}$ and $\mathrm{CO}_{2} . J^{\mathrm{R}}$ was zero under these conditions. When bathing solution $\mathrm{pH}$ was reduced from 7.59 to 7.09 , very small but significant changes were noted in Isc, PD, G, and the mucosal to serosal and net fluxes of $\mathrm{Na}$ and $\mathrm{Cl}$. These changes were qualitatively similar to, although much smaller than, those seen when a similar $\mathrm{pH}$ change was induced by altering $\mathrm{PCO}_{2}$ (Table I). In addition, the decreases in Isc and 


\begin{tabular}{|c|c|c|c|c|c|c|c|c|c|c|c|}
\hline \multirow[b]{2}{*}{$\mathrm{PCO}_{2}$} & \multirow[b]{2}{*}{$\mathrm{pH}$} & \multirow[b]{2}{*}{ Isc } & \multirow[b]{2}{*}{ PD } & \multirow[b]{2}{*}{$\mathbf{G}$} & \multicolumn{3}{|c|}{$\mathrm{Na}$ flux } & \multicolumn{3}{|c|}{$\mathrm{Cl}$ flux } & \multirow[b]{2}{*}{$J^{R}$} \\
\hline & & & & & $J \mathrm{~ms}$ & Jsm & Jnet & $J \mathrm{~ms}$ & $J$ sm & Jnet & \\
\hline$m m H g$ & & $\begin{array}{c}\mu e q / \mathrm{cm}^{2} \\
\operatorname{per} h\end{array}$ & $m V$ & $\begin{array}{l}\mathrm{mS} / \\
\mathrm{cm}^{2}\end{array}$ & \multicolumn{3}{|c|}{$\mu e q / \mathrm{cm}^{2}$ per $h$} & \multicolumn{3}{|c|}{$\mu e q / \mathrm{cm}^{2}$ per $h$} & \\
\hline \multirow[t]{2}{*}{0} & 8.42 & 1.8 & 4.4 & 11.1 & 5.9 & 6.1 & -0.2 & 7.4 & 8.9 & -1.5 & 0.4 \\
\hline & \pm 0.03 & \pm 0.1 & \pm 0.1 & \pm 0.4 & \pm 0.3 & \pm 0.3 & \pm 0.3 & \pm 0.4 & \pm 0.6 & \pm 0.4 & \pm 0.5 \\
\hline 21.6 & 7.63 & 1.6 & 5.0 & 8.9 & 9.2 & 5.0 & 4.2 & 12.8 & 8.0 & 4.8 & 2.2 \\
\hline \pm 0.7 & \pm 0.01 & \pm 0.2 & \pm 0.5 & \pm 0.6 & \pm 0.5 & \pm 0.3 & \pm 0.4 & \pm 0.5 & \pm 0.3 & \pm 0.5 & \pm 0.3 \\
\hline 34.5 & 7.41 & 1.4 & 4.7 & 8.5 & 10.1 & 4.7 & 5.5 & 14.6 & 8.0 & 6.6 & 2.5 \\
\hline \pm 0.8 & \pm 0.01 & \pm 0.2 & \pm 0.7 & \pm 0.6 & \pm 0.8 & \pm 0.2 & \pm 0.8 & \pm 0.8 & \pm 0.4 & \pm 0.8 & \pm 0.4 \\
\hline 69.6 & 7.10 & 0.9 & 3.2 & 7.9 & 11.7 & 4.8 & 6.8 & 16.5 & 9.0 & 7.6 & 1.7 \\
\hline \pm 1.2 & \pm 0.01 & \pm 0.1 & \pm 0.5 & \pm 0.5 & \pm 0.9 & \pm 0.3 & \pm 0.6 & \pm 0.7 & \pm 0.4 & \pm 0.7 & \pm 0.3 \\
\hline$<0.001$ & $<0.001$ & $<0.025$ & & & $<0.01$ & & $<0.001$ & $<0.001$ & & $<0.001$ & $<0.05$ \\
\hline
\end{tabular}

Values are means \pm SE. Number of tissue pairs studied at a $\mathrm{PCO}_{2}$ of $0=4$, at a $\mathrm{PCO}_{2}$ of $21.6=17$, at a $\mathrm{PCO}_{2}$ of $34.5=15$, and at a $\mathrm{PCO}_{2} 69.6$ $=17$. Data were obtained in separate groups of tissue pairs bathed in $140 \mathrm{mM} \mathrm{Na}$ and $21 \mathrm{mM} \mathrm{HCO} \mathrm{H}_{3}-\mathrm{Ringer}^{2}$ solutions at one or more $\mathrm{CO}_{2}$ tensions. * Four experimental groups were compared by one-way analysis of variance.

PD in Hepes buffer were entirely accounted for by increases in net $\mathrm{Cl}$ transport since as shown in Table II, Isc $=J_{\text {net }}^{\mathrm{Na}}-J_{\text {net }}^{\mathrm{C}}$ and $J^{\mathbf{R}}=0$.

We then examined the possibility that the concentration of $\mathrm{HCO}_{3}$ altered the effect of $\mathrm{CO}_{2}$ on $\mathrm{Na}$ and $\mathrm{Cl}$ absorption. We measured ion fluxes in the 39-mM $\mathrm{HCO}_{3}$ Ringer's solution at $\mathrm{CO}_{2}=69.6 \mathrm{mmHg}(\mathrm{pH} 7.35)$ and in the $11-\mathrm{mM} \mathrm{HCO}_{3}$ Ringer's solution at $\mathrm{PCO}_{2}=21.6 \mathrm{mmHg}(\mathrm{pH} 7.35)$. The differences in net $\mathrm{Na}$ flux $\left(1.3 \mu \mathrm{eq} / \mathrm{cm}^{2}\right.$ per $\left.\mathrm{h}\right)$, net $\mathrm{Cl}$ flux $(3.6$ $\mu \mathrm{eq} / \mathrm{cm}^{2}$ per h), Isc ( $-0.9 \mu \mathrm{eq} / \mathrm{cm}^{2}$ per $\left.\mathrm{h}\right)$, and $G\left(0.1 \mathrm{mS} / \mathrm{cm}^{2}\right)$ at these $\mathrm{CO}_{2}$ tensions were similar to the differences observed between similar $\mathrm{PCO}_{2}$ levels in the $21-\mathrm{mM} \mathrm{HCO}$ Ringer's solution shown in Table $I$.
The relative effects of bathing solution $\mathrm{PCO}_{2}, \mathrm{pH}$, and $\mathrm{HCO}_{3}$ concentration on ion flux were confirmed by correlating these variables in all 75 tissue pairs in all the acid-base groups described above (except the groups exposed to room air or bathed in Hepes-Ringer's solution). As shown in Fig. 1, net sodium absorption correlated only with bathing solution $\mathrm{PCO}_{2}$ $(r=0.83, P<0.02)$ and did not correlate with either $\mathrm{pH}$ or $\mathrm{HCO}_{3}$ concentration. When unidirectional fluxes were examined, $J_{\mathrm{ms}}^{\mathrm{Na}}$ correlated with $\mathrm{PCO}_{2}(r=0.97, P<0.001)$. The slopes of both of these relations were 0.04 , indicating that for each $10-\mathrm{mmHg}$ increment in $\mathrm{PCO}_{2}, J_{\text {net }}^{\mathrm{Na}}$ flux increased 0.4 $\mu \mathrm{eq} / \mathrm{cm}^{2}$ per $\mathrm{h}$.

Although the relation between $\mathrm{CO}_{2}$ and chloride absorp-

Table II. Effect of pH on Colonic Electrolyte Transport in $\mathrm{HCO}_{3}$ and Hepes-buffered Ringer's Solutions

\begin{tabular}{|c|c|c|c|c|c|c|c|c|c|c|c|c|c|}
\hline & \multirow[b]{2}{*}{$\mathrm{HCO}_{3}$} & \multirow[b]{2}{*}{$\mathrm{PCO}_{2}$} & \multirow[b]{2}{*}{$\mathrm{pH}$} & \multirow[b]{2}{*}{ Isc } & \multirow[b]{2}{*}{ PD } & \multirow[b]{2}{*}{$\mathbf{G}$} & \multicolumn{3}{|c|}{$\mathrm{Na}$ flux } & \multicolumn{3}{|c|}{$\mathrm{Cl}$ flux } & \multirow[b]{2}{*}{$J^{\mathbf{R}}$} \\
\hline & & & & & & & $J \mathrm{~ms}$ & $J$ sm & Jnet & $J \mathrm{~ms}$ & $J \mathrm{sm}$ & Jnet & \\
\hline & $m M$ & $m m H g$ & & $\mu e q / \mathrm{cm}^{2}$ per $h$ & $m V$ & $\mathrm{mS} / \mathrm{cm}^{2}$ & \multicolumn{3}{|c|}{$\mu e q / \mathrm{cm}^{2}$ per $h$} & \multicolumn{3}{|c|}{$\mu e q / c^{2} \operatorname{per} h$} & \\
\hline $\mathrm{HCO}_{3}$ & 39 & 35.8 & 7.65 & 1.3 & 3.8 & 9.2 & 10.2 & 5.7 & 4.5 & 13.2 & 7.4 & 5.8 & 2.6 \\
\hline \multirow[t]{3}{*}{ Ringer's } & & \pm 1.0 & \pm 0.01 & \pm 0.1 & \pm 0.4 & \pm 0.6 & \pm 0.7 & \pm 0.7 & \pm 0.8 & \pm 0.7 & \pm 0.7 & \pm 0.7 & \pm 0.4 \\
\hline & 11 & 34.3 & 7.14 & 1.4 & 5.2 & 7.8 & 10.4 & 5.4 & 5.1 & 15.8 & 10.4 & 5.4 & 1.7 \\
\hline & & \pm 0.7 & \pm 0.01 & \pm 0.2 & \pm 0.8 & \pm 2.1 & \pm 0.7 & \pm 0.3 & \pm 0.8 & \pm 0.9 & \pm 0.4 & \pm 0.8 & \pm 0.4 \\
\hline$P^{*}$ & & & $<0.001$ & & $<0.001$ & & & & & $<0.05$ & $<0.001$ & & \\
\hline Hepes & 0 & 0 & 7.59 & 1.7 & 6.5 & 7.0 & 5.5 & 4.4 & 1.1 & 8.1 & 8.4 & -0.2 & 0.3 \\
\hline \multirow[t]{3}{*}{ Ringer's } & & & \pm 0.01 & \pm 0.1 & \pm 0.6 & \pm 0.2 & \pm 0.2 & \pm 0.2 & \pm 0.4 & \pm 0.7 & \pm 0.5 & \pm 0.8 & \pm 0.5 \\
\hline & 0 & 0 & 7.09 & 1.3 & 5.7 & 6.2 & 6.1 & 4.0 & 2.2 & 8.9 & 7.7 & 1.2 & 0.3 \\
\hline & & & \pm 0.01 & \pm 0.2 & \pm 0.7 & \pm 0.3 & \pm 0.4 & \pm 0.3 & \pm 0.6 & \pm 0.7 & \pm 0.5 & \pm 0.8 & \pm 0.3 \\
\hline$P^{\ddagger}$ & & & $<0.001$ & $<0.005$ & $<0.05$ & $<0.001$ & $<0.05$ & $<0.01$ & $<0.01$ & $<0.025$ & $<0.005$ & $<0.005$ & \\
\hline
\end{tabular}

Values are means \pm SE. Number of tissue pairs studied at $39 \mathrm{mM} \mathrm{HCO}_{3}-$ Ringer's solution $=12,11 \mathrm{mM} \mathrm{HCO}$-Ringer's $=14$, and $21 \mathrm{mM}$ Hepes = 9. Data for $\mathrm{HCO}_{3}$-Ringer's solution were obtained in separate groups of tissue pairs bathed in $39 \mathrm{HCO}_{3}-\mathrm{Ringer}$ 's solution or $11 \mathrm{mM}$ $\mathrm{HCO}_{3}$-Ringer's solution. Data for Hepes-Ringer's solution were obtained in one group of tissues bathed in 21 mM Hepes-Ringer's solution titrated during consecutive periods with $\mathrm{HCl}$ or $\mathrm{NaOH}$. * Unpaired $t$ test, ${ }^{*}$ paired $t$ test. 


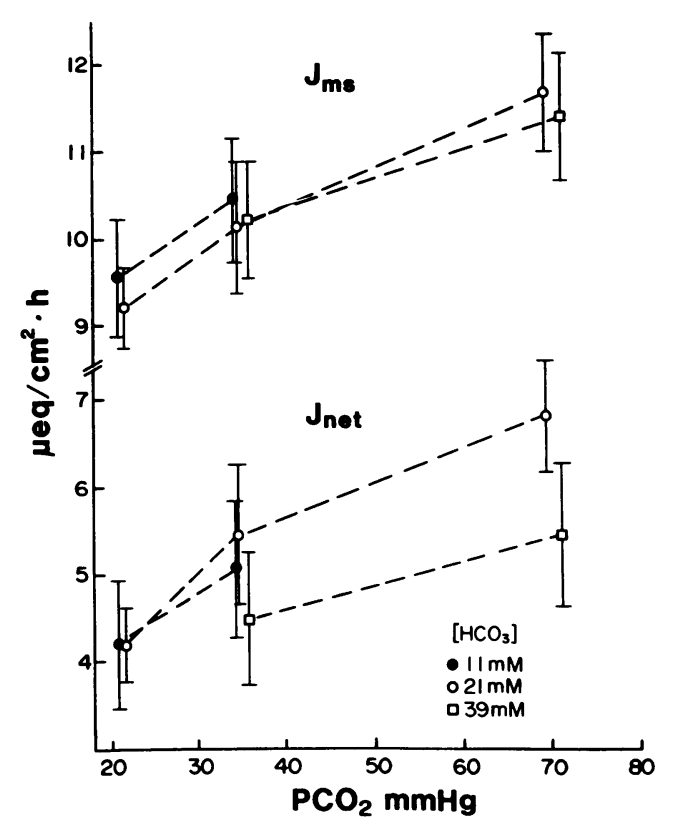

Figure 1. Relation of sodium absorption to bathing solution $\mathrm{PCO}_{2}$. $J_{\mathrm{ms}}^{\mathrm{Na}}$ and $J_{\text {net }}^{\mathrm{Na}}$ were measured in Ringer's solutions containing 11, 21, or $39 \mathrm{mM} \mathrm{HCO}$ during consecutive periods in which $\mathrm{PCO}_{2}$ was altered as indicated by the dashed lines. Both $J_{\mathrm{ms}}^{\mathrm{Na}}$ and $J_{\mathrm{net}}^{\mathrm{Na}}$ increased with increasing $\mathrm{PCO}_{2}$. Values are means $\pm \mathrm{SE}$.

tion appeared to be curvilinear (Fig. 2), when analyzed by linear regression analysis, similar results were obtained for chloride flux. Net chloride absorption correlated with $\mathrm{PCO}_{2}(r$ $=0.92, P<0.005$ ), but not with either $\mathrm{pH}$ or $\mathrm{HCO}_{3}$ concentration. A correlation also was found for $J_{\mathrm{ms}}^{\mathrm{Cl}}$ and $\mathrm{PCO}_{2}(r$ $=0.72, P<0.05$ ). The slopes of these relations were similar to the slope relating sodium flux to $\mathrm{PCO}_{2}$. There was an $\sim 0.6$ $\mu \mathrm{eq} / \mathrm{cm}^{2}$ per $\mathrm{h}$ increase in $J_{\text {net }}^{\mathrm{Cl}}$ per $10-\mathrm{mmHg}$ increase in $\mathrm{PCO}_{2}$.

\section{Inhibitors}

In another series of experiments, inhibitors of various electrolyte transport processes were added to $21 \mathrm{mM} \mathrm{HCO} 3$ Ringer's bathing solution and the effect of increasing $\mathrm{CO}_{2}$ tension was measured. Alterations in $\mathrm{Na}$ and $\mathrm{Cl}$ fluxes in the presence and absence of the inhibitor were then compared.

Acetazolamide. To examine the effect of inhibiting mucosal carbonic anhydrase activity, $0.1 \mathrm{mM}$ sodium acetazolamide was added to both mucosal and serosal bathing solutions. At $\mathrm{PCO}_{2}=21.6 \mathrm{mmHg}$, this addition reduced $\mathrm{Jms}$ and Jnet for chloride $\sim 50 \%$ (Table III). As shown in Table IV, however, the increments in net sodium and chloride flux caused by increasing $\mathrm{PCO}_{2}$ from 21.6 to $69.6 \mathrm{mmHg}$, although somewhat smaller, were not significantly different in the presence and absence of acetazolamide. The presence of acetazolamide nevertheless was associated with an increase in $J^{R}$ in response to this increase in $\mathrm{PCO}_{2}$.

This partial effect of acetazolamide suggested the possibility that the $48-\mathrm{mmHg}$ increase in $\mathrm{CO}_{2}$ tension (69.6 minus $21.6 \mathrm{mmHg}$ ) had overcome the effects of $0.1 \mathrm{mM}$ acetazolamide. The effect of increasing $\mathrm{PCO}_{2}$ from 21.6 to $58.6 \mathrm{mmHg}$ on net sodium and chloride fluxes was therefore compared with the increments caused by increasing $\mathrm{PCO}_{2}$ from 21.6 to $69.6 \mathrm{mmHg}$. In fact, these increments were similar. When

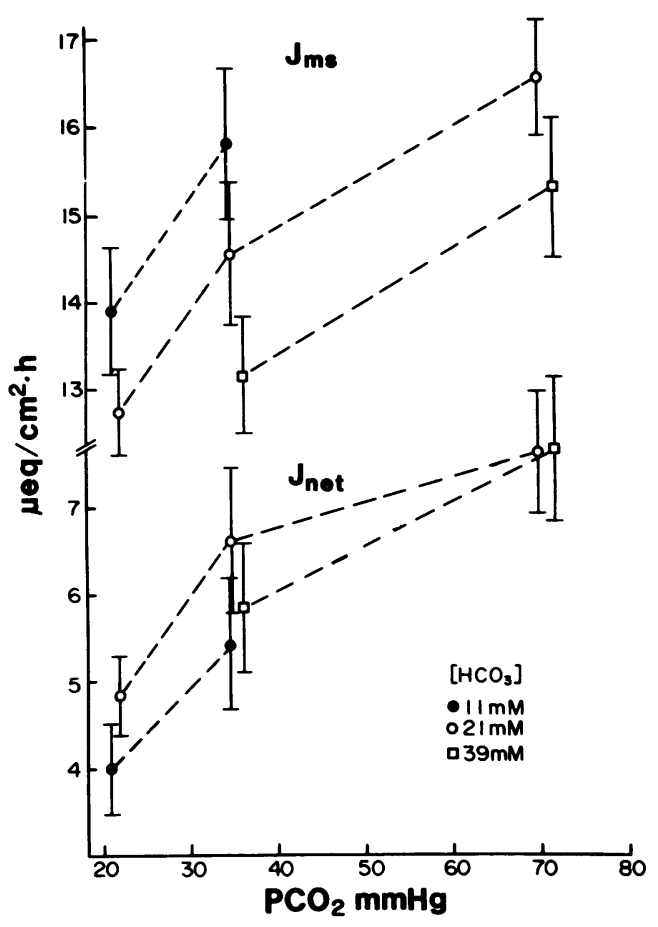

Figure 2. Relation of chloride absorption to bathing solution $\mathrm{PCO}_{2}$. $J_{\mathrm{ms}}^{\mathrm{cl}}$ and $J_{\text {net }}^{\mathrm{C}}$ were measured in Ringer's solutions containing 11,21 , or $39 \mathrm{mM} \mathrm{HCO}$ during consecutive periods in which $\mathrm{PCO}_{2}$ was altered as indicated by the dashed lines. Both $J_{\mathrm{ms}}^{\mathrm{C}}$ and $J_{\text {net }}^{\mathrm{q}}$ increased with increasing $\mathrm{PCO}_{2}$. Values are means $\pm \mathrm{SE}$.

$\mathrm{PCO}_{2}$ was raised from 21.6 to $58.6 \mathrm{mmHg}$ in the presence of $0.1 \mathrm{mM}$ acetazolamide, $J_{\text {net }}^{\mathrm{Na}}$ increased from $2.7 \pm 0.8$ to $5.0 \pm 1.2$ $\mu \mathrm{eq} / \mathrm{cm}^{2}$ per $\mathrm{h}$ and $J_{\text {net }}^{\mathrm{Cl}}$ increased from $2.8 \pm 0.7$ to $6.7 \pm 1.0$ $\mu \mathrm{eq} / \mathrm{cm}^{2}$ per $\mathrm{h}$ (compare with Tables III and IV). These findings suggested that a $0.1-\mathrm{mM}$ concentration of acetazolamide was insufficient to completely inhibit mucosal carbonic anhydrase in our system. Consequently, we repeated the experiment in the presence of $1.0 \mathrm{mM}$ acetazolamide. Under these conditions, $J \mathrm{~ms}$ for both sodium and chloride were markedly reduced, resulting in zero net sodium absorption and net chloride secretion at $\mathrm{PCO}_{2}=21.6 \mathrm{mmHg}$. In addition, Isc tended to decrease and $J^{\mathrm{R}}$ changed direction (Table III). When $\mathrm{PCO}_{2}$ was increased from 21.6 to $69.6 \mathrm{mmHg}$, the increases in Jms for both $\mathrm{Na}$ and $\mathrm{Cl}$ were significantly smaller than in the absence of acetazolamide (Table IV).

Amiloride. The participation of electrogenic $\mathrm{Na}$ transport and $\mathrm{Na} / \mathrm{H}$ exchange in the colonic response to $\mathrm{PCO}_{2}$ were examined by adding $0.75 \mathrm{mM}$ amiloride to the mucosal bathing solution. At a $\mathrm{CO}_{2}$ tension of $21.6 \mathrm{mmHg}$, amiloride decreased $J_{\mathrm{ms}}^{\mathrm{Na}} 43 \%, J_{\text {net }}^{\mathrm{Na}} 69 \%$, and $J_{\mathrm{ms}}^{\mathrm{Cl}} 23 \%$ (Table III). As shown in Table IV, the presence of amiloride markedly reduced but did not completely prevent the increments in $J_{\mathrm{ms}}^{\mathrm{Na}}$ and $J_{\text {net }}^{\mathrm{Na}}$ produced by increasing the $\mathrm{PCO}_{2}$ to $69.6 \mathrm{mmHg}$. In addition, the increments in $J_{\mathrm{ms}}^{\mathrm{Cl}}$ and $J_{\text {net }}^{\mathrm{Cl}}$ caused by increasing $\mathrm{PCO}_{2}$ were unaffected by the presence of amiloride. These increments in chloride flux were associated with increases in $J^{R}$ that were not observed in the absence of amiloride.

We also studied amiloride in a $\mathrm{HCO}_{3}$-Ringer's bathing solution in which the sodium concentration was reduced to 50 $\mathrm{mM}$ (Table V). In the absence of amiloride, increases in $\mathrm{PCO}_{2}$ 
Table III. Effect of Various Inhibitors on Colonic Electrolyte Transport at a $\mathrm{PCO}_{2}$ of $21.6 \mathrm{mmHg}$

\begin{tabular}{|c|c|c|c|c|c|c|c|c|c|c|}
\hline \multirow[b]{2}{*}{ Addition } & \multirow[b]{2}{*}{$I s c^{*}$} & \multirow[b]{2}{*}{ PD } & \multirow[b]{2}{*}{$G^{*}$} & \multicolumn{3}{|c|}{$\mathrm{Na}$ flux } & \multicolumn{3}{|c|}{$\mathrm{Cl}$ flux } & \multirow[b]{2}{*}{$J^{\mathbf{R}}$} \\
\hline & & & & $J \mathbf{m s}^{t}$ & $J$ sm & $J$ net $^{4}$ & $\mathrm{Jms}^{ \pm}$ & Jsm & Jnet & \\
\hline & $\mu e q / \mathrm{cm}^{2}$ per $h$ & $m V$ & $\mathrm{mS} / \mathrm{cm}^{2}$ & \multicolumn{3}{|c|}{$\mu e q / \mathrm{cm}^{2}$ per $h$} & \multicolumn{3}{|c|}{$\mu e q / \mathrm{cm}^{2} \operatorname{per} h$} & \\
\hline \multirow[t]{2}{*}{ None } & 1.6 & 5.0 & 8.9 & 9.2 & 5.0 & 4.2 & 12.8 & 8.0 & 4.8 & 2.2 \\
\hline & \pm 0.2 & \pm 0.5 & \pm 0.6 & \pm 0.5 & \pm 0.3 & \pm 0.4 & \pm 0.5 & \pm 0.3 & \pm 0.4 & \pm 0.3 \\
\hline \multirow[t]{2}{*}{ Acetazolamide (0.1 mM) } & 1.3 & 4.8 & 8.4 & $7: 7$ & 5.1 & 2.6 & $10.2^{8}$ & 8.1 & $2.1^{\prime \prime}$ & 0.8 \\
\hline & \pm 0.1 & \pm 0.7 & \pm 0.7 & \pm 0.7 & \pm 0.5 & \pm 0.6 & \pm 0.7 & \pm 0.4 & \pm 0.5 & \pm 0.6 \\
\hline \multirow[t]{2}{*}{ Acetazolamide (1.0 mM) } & 0.9 & 4.2 & $5.7^{8}$ & $3.8^{\prime \prime}$ & 3.8 & $0.0^{\prime \prime}$ & $5.3^{11}$ & 7.6 & $-2.3^{\prime \prime}$ & $-1.3^{\prime \prime}$ \\
\hline & \pm 0.2 & \pm 0.5 & \pm 0.4 & \pm 0.1 & \pm 0.2 & \pm 0.2 & \pm 0.4 & \pm 0.7 & \pm 0.5 & \pm 0.5 \\
\hline \multirow[t]{2}{*}{ Amiloride (0.75 mM) } & 1.2 & 6.2 & $5.4^{41}$ & $5.0^{\prime \prime}$ & 3.7 & $1.3^{8}$ & $10.0^{5}$ & 6.9 & 3.1 & 3.1 \\
\hline & \pm 0.1 & \pm 0.4 & \pm 0.5 & \pm 0.5 & \pm 0.4 & \pm 0.7 & \pm 0.7 & \pm 0.7 & \pm 0.8 & \pm 0.6 \\
\hline \multirow[t]{2}{*}{ DIDS (0.1 mM) } & 2.0 & 7.4 & 7.7 & $6.3^{8}$ & 4.5 & $1.8^{\S}$ & $10.0^{8}$ & 7.9 & 2.1 & 2.3 \\
\hline & \pm 0.0 & \pm 1.0 & \pm 0.4 & \pm 0.7 & \pm 0.3 & \pm 0.8 & \pm 0.7 & \pm 0.5 & \pm 1.2 & \pm 0.4 \\
\hline \multirow[t]{2}{*}{ Furosemide (0.1 mM) } & 1.6 & 6.3 & 7.3 & $6.5^{8}$ & 4.6 & $1.9^{8}$ & $9.6^{8}$ & 7.6 & $2.0^{8}$ & 1.8 \\
\hline & \pm 0.3 & \pm 1.2 & \pm 0.4 & \pm 0.7 & \pm 0.4 & \pm 1.1 & \pm 0.8 & \pm 0.4 & \pm 0.6 & \pm 0.6 \\
\hline Amiloride $(0.75 \mathrm{mM})$ & 1.7 & 6.4 & 7.1 & $4.1^{11}$ & 4.5 & $-0.4^{\prime \prime}$ & $8.8^{\prime \prime}$ & 9.4 & $-0.6^{\prime \prime}$ & 1.6 \\
\hline Furosemide $(0.1 \mathrm{mM})$ & \pm 0.3 & \pm 0.9 & \pm 0.3 & \pm 0.4 & \pm 0.3 & \pm 0.5 & \pm 0.5 & \pm 0.5 & \pm 0.6 & \pm 0.6 \\
\hline
\end{tabular}

Values are means $\pm S E$. Number of tissue pairs studied with no addition $=17,0.1 \mathrm{mM}$ acetazolamide $=15,1.0 \mathrm{mM}$ acetazolamide $=6,0.75$ $\mathrm{mM}$ amiloride $=8,0.1 \mathrm{mM}$ DIDS $=6,0.1 \mathrm{mM}$ furosemide $=6$, and $0.75 \mathrm{mM}$ amiloride plus $0.1 \mathrm{mM}$ furosemide $=7$. Separate groups of tissue pairs were studied in $140 \mathrm{mM} \mathrm{Na}$ and $21 \mathrm{mM} \mathrm{HCO}_{3}$-Ringer's solution at a $\mathrm{CO}_{2}$ tension of $21.6 \mathrm{mmHg}(\mathrm{pH} 7.63)$. ${ }^{*} P<0.002,{ }^{\ddagger} P$ $<0.001$ when the mean values for all groups were compared by one-way analysis of variance. $8<0.05$, $P<0.005$ when compared with addition: none by unpaired $t$ test.

Table IV. Effect of Increasing $\mathrm{PCO}_{2}$ on Colonic Electrolyte Transport in the Presence of Various Inhibitors

\begin{tabular}{|c|c|c|c|c|c|c|c|c|c|c|}
\hline \multirow[b]{2}{*}{ Addition } & \multirow[b]{2}{*}{$\Delta / s c$} & \multirow[b]{2}{*}{$\Delta \mathrm{PD}$} & \multirow[b]{2}{*}{$\Delta \mathbf{G}$} & \multicolumn{3}{|c|}{$\Delta \mathrm{Na}$ flux } & \multicolumn{3}{|c|}{$\Delta \mathrm{Cl}$ flux } & \multirow[b]{2}{*}{$\Delta J^{R}$} \\
\hline & & & & Jms & $J \mathbf{s m}$ & Jnet & Jms & $J \mathrm{sm}$ & Jnet & \\
\hline & $\mu e q / \mathrm{cm}^{2}$ per $h$ & $m V$ & $\mathrm{mS} / \mathrm{cm}^{2}$ & \multicolumn{3}{|c|}{$\mu e q / \mathrm{cm}^{2}$ per $h$} & \multicolumn{3}{|c|}{$\mu e q / \mathrm{cm}^{2}$ per $h$} & \\
\hline \multirow[t]{2}{*}{ None } & -0.7 & -1.8 & -1.0 & 2.5 & -0.2 & 2.6 & 3.8 & 1.0 & 2.8 & -0.6 \\
\hline & \pm 0.1 & \pm 0.4 & \pm 0.2 & \pm 0.5 & \pm 0.1 & \pm 0.5 & \pm 0.4 & \pm 0.3 & $\pm 0 . \dot{5}$ & \pm 0.3 \\
\hline \multirow[t]{2}{*}{ Acetazolamide (0.1 mM) } & -0.6 & -2.7 & -1.1 & 1.5 & -0.5 & 2.0 & 3.0 & $-0.6^{*}$ & 3.6 & $1.0^{*}$ \\
\hline & \pm 0.2 & $\pm 0 . \dot{5}$ & \pm 0.2 & \pm 0.3 & \pm 0.2 & \pm 0.4 & \pm 0.7 & \pm 0.4 & \pm 0.7 & \pm 0.6 \\
\hline \multirow[t]{2}{*}{ Acetazolamide (1.0 mM) } & -0.4 & -1.5 & -0.5 & $0.9^{*}$ & -0.4 & $1.3^{*}$ & $1.1^{*}$ & $-1.5^{*}$ & 2.6 & $0.9^{*}$ \\
\hline & \pm 0.1 & \pm 0.4 & \pm 0.2 & \pm 0.2 & \pm 0.3 & \pm 0.4 & \pm 0.3 & \pm 0.5 & \pm 0.4 & \pm 0.4 \\
\hline \multirow[t]{2}{*}{ Amiloride $(0.75 \mathrm{mM})$} & -0.7 & -2.9 & -0.8 & $0.6^{*}$ & -0.5 & $1.1^{*}$ & 3.2 & 0.4 & 2.8 & $0.9^{*}$ \\
\hline & \pm 0.9 & \pm 0.5 & \pm 0.7 & \pm 0.2 & \pm 0.2 & \pm 0.2 & \pm 0.2 & \pm 0.3 & \pm 0.3 & \pm 0.3 \\
\hline \multirow[t]{2}{*}{ DIDS (0.1 mM) } & -1.0 & $-3.3^{*}$ & -1.3 & 2.5 & -0.1 & 2.6 & 3.9 & 0.2 & 3.6 & 0.0 \\
\hline & \pm 0.2 & \pm 0.9 & \pm 0.2 & \pm 0.7 & \pm 0.3 & \pm 0.9 & \pm 0.8 & \pm 0.6 & \pm 0.5 & \pm 0.5 \\
\hline \multirow[t]{2}{*}{ Furosemide (0.1 mM) } & -0.6 & -1.8 & -0.9 & 1.9 & -0.5 & 2.4 & 2.9 & 0.2 & 2.8 & -0.2 \\
\hline & \pm 0.2 & \pm 0.6 & \pm 0.2 & \pm 0.4 & \pm 0.2 & \pm 0.4 & \pm 0.6 & \pm 0.3 & \pm 0.5 & \pm 0.2 \\
\hline Amiloride (0.75 mM) & -0.7 & -2.3 & -0.8 & $0.2^{*}$ & $-0.5^{*}$ & $0.7^{*}$ & $2.5^{*}$ & 0.5 & 2.0 & $0.5^{*}$ \\
\hline Furosemide (0.1 mM) & \pm 0.2 & \pm 0.7 & \pm 0.2 & \pm 0.3 & \pm 0.1 & \pm 0.3 & \pm 0.5 & \pm 0.3 & \pm 0.5 & \pm 0.4 \\
\hline
\end{tabular}

Values are means $\pm \mathrm{SE}$. Number of tissue pairs studied with no addition $=17$, with $0.1 \mathrm{mM}$ acetazolamide $=15$, with $1.0 \mathrm{mM}$ acetazolamide $=6$, with $0.75 \mathrm{mM}$ amiloride $=8$, with $0.1 \mathrm{mM}$ DIDS $=6$, with $0.1 \mathrm{mM}$ furosemide $=6$, and with $0.75 \mathrm{mM}$ amiloride plus $0.1 \mathrm{mM}$ furosemide $=7$. Separate groups of tissue pairs were studied in $140 \mathrm{mM} \mathrm{Na}$ and $21 \mathrm{mM}^{\mathrm{H}} \mathrm{HCO}_{3}$-Ringer's solution at $\mathrm{CO}_{2}$ tensions of $21.6(\mathrm{pH} 7.63$ ) and $69.6 \mathrm{mmHg}$ (pH 7.10). Data (deltas) represent the differences between values at $69.6 \mathrm{mmHg}$ minus values at $21.6 \mathrm{mmHg}$. Data for addition: none were derived from experiments presented in Table $\mathrm{I} .{ }^{*} P<0.05$ when compared with addition: none by unpaired $t$ test. 
caused qualitatively and quantitatively similar changes in ion flux, as were observed in a bathing solution containing 140 $\mathrm{mM}$ sodium (compare Tables IV and V). The effect of amiloride at a $\mathrm{PCO}_{2}$ of $21.6 \mathrm{mmHg}$ also was similar at 50 and 140 mM sodium: amiloride reduced $J_{\text {net }}^{\mathrm{Na}} 70 \%$ and $J_{\text {net }}^{\mathrm{Cl}} 47 \%$, and increased $J^{\mathrm{R}}$. Nevertheless, when the $\mathrm{PCO}_{2}$ was raised in 50 $\mathrm{mM}$ sodium Ringer's solution, amiloride completely inhibited the increases in $J_{\mathrm{ms}}^{\mathrm{Na}}$ and $J_{\text {net }}^{\mathrm{Na}}$.

Furosemide. To determine whether a cotransport process was involved in the colonic response to $\mathrm{CO}_{2}, 0.1 \mathrm{mM}$ furosemide was added to the mucosal bathing solution. At $\mathrm{PCO}_{2}$ $=21.6 \mathrm{mmHg}$, furosemide decreased $J_{\text {net }}^{\mathrm{Na}} 55 \%$ and $J_{\text {net }}^{\mathrm{Cl}} 67 \%$, respectively (Table III). This effect was additive to that of amiloride: the mucosal addition of both amiloride and furosemide at $\mathrm{PCO}_{2}=21.6 \mathrm{mmHg}$ resulted in $J_{\text {net }}^{\mathrm{Na}}(P<0.05)$ and $J_{\text {net }}^{\mathrm{C}}(P$ $<0.005$ ) values that were significantly lower than for amiloride alone. In fact, $J_{\text {net }}^{\mathrm{Na}}$ and $J_{\text {net }}^{\mathrm{C}}$ did not differ from zero under these conditions.

Despite this effect of furosemide at $\mathrm{PCO}_{2}=21.6 \mathrm{mmHg}$, a furosemide-inhibitable process did not appear to participate in the colonic response to $\mathrm{PCO}_{2}$. As shown in Table IV, furosemide did not alter the increments in $J_{\text {net }}^{\mathrm{Na}}$ or $J_{\text {net }}^{\mathrm{C}}$ caused by increasing bathing solution $\mathrm{PCO}_{2}$ to $69.6 \mathrm{mmHg}$. Nevertheless, it was possible that in the presence of amiloride, a role for this process might be revealed. The effect of $\mathrm{CO}_{2}$, therefore, was measured in tissues exposed to mucosal furosemide in a 21-mM $\mathrm{HCO}_{3}$ Ringer's solution containing amiloride. As shown in Table IV, the increments in $J_{\text {net }}^{\mathrm{Na}}$ and $J_{\text {net }}^{\mathrm{Cl}}$ in response to increasing $\mathrm{PCO}_{2}$ under these conditions were no different than in tissues exposed to similar $\mathrm{PCO}_{2}$ changes in the presence of amiloride alone: $\Delta J_{\text {net }}^{\mathrm{Na}} 0.7 \pm 0.3$ vs. $1.1 \pm 0.2 \mu \mathrm{eq} / \mathrm{cm}^{2} \mathrm{per} \mathrm{h}$, NS; $\Delta J_{\text {net }}^{\mathrm{Cl}} 2.0 \pm 0.5$ vs. $2.8 \pm 0.3 \mu \mathrm{eq} / \mathrm{cm}^{2}$ per h, NS).

DIDS. The addition of DIDS to the mucosal bathing solution at a final concentration of $0.1 \mathrm{mM}$ reduced $J_{\mathrm{ms}}^{\mathrm{Na}}, J_{\mathrm{net}}^{\mathrm{Na}}$, and $J_{\mathrm{ms}}^{\mathrm{Cl}}$ at $\mathrm{PCO}_{2}=21.6 \mathrm{mmHg}$. A similar reduction in $J_{\text {net }}^{\mathrm{C}}$ did not reach statistical significance. Nevertheless, DIDS at $0.1 \mathrm{mM}$ or at a 10-fold higher concentration did not alter the increments in $J_{\text {net }}^{\mathrm{Na}}$ or $J_{\text {net }}^{\mathrm{Cl}}$ induced by increasing the $\mathrm{PCO}_{2}$ to $69.6 \mathrm{mmHg}$ (data for $0.1 \mathrm{mM}$ DIDS shown in Table IV).

\section{Discussion}

In previous studies we reported that physiologic changes in arterial $\mathrm{PCO}_{2}$ have major effects on electrolyte and water absorption in the rat colon (1-3). The in vivo experimental conditions, however, allowed only tentative conclusions regarding the specificity and site of action of $\mathrm{CO}_{2}(11,13)$. The current findings confirm that the action of $\mathrm{CO}_{2}$ on sodium and chloride absorption is predominant among the acid-base variables, and represents a local effect of $\mathrm{CO}_{2}$ on the intestinal mucosa. A significant effect of $\mathrm{pH}$ was ruled out by the sabsence of a correlation between bathing solution $\mathrm{pH}$ and either $J_{\text {net }}^{\mathrm{Na}}$ or $J_{\text {net }}^{\mathrm{C}}$, and by the minimal effect of $\mathrm{pH}$ on ion flux (between 7.09 and 7.65) when $\mathrm{PCO}_{2}$ remained unchanged. The overall magnitude of the $\mathrm{CO}_{2}$ effect was of interest as well: $J_{\text {net }}^{\mathrm{Na}}$ and $J_{\text {net }}^{\mathrm{Cl}}$ increased $\sim 0.5 \mu \mathrm{eq} / \mathrm{cm}^{2}$ per $\mathrm{h}$ per $10-\mathrm{mmHg}$ increase in $\mathrm{PCO}_{2}$. These increments are equivalent to the $60 \%$ increases in sodium and chloride absorption observed in vivo over a similar range of $\mathrm{CO}_{2}$ tensions $(2 \mu \mathrm{eq} / \mathrm{cm}$ length per $\mathrm{h}$ per $10-\mathrm{mmHg}$ change in arterial $\left.\mathrm{PCO}_{2}\right)(2,3)$.

The colonic transport pathways affected by $\mathrm{CO}_{2}$ appear to be active, electroneutral sodium and chloride absorptive processes. The importance of electroneutral absorption was originally suggested during in vivo studies of rat colon by the minimal changes in PD, and the equivalent increases in net sodium and chloride absorption in response to increases in arterial $\mathrm{PCO}_{2}(2,3,12)$. In addition, the rabbit distal colon, which absorbs sodium by conductive, electrogenic pathways (16), did not respond at all to alterations in arterial $\mathrm{PCO}_{2}$ (17). The nature of this electroneutral process remained uncertain, however, although the in vivo data were most consistent with the participation of $\mathrm{Na} / \mathrm{H}$ and $\mathrm{Cl} / \mathrm{HCO}_{3}$ ion exchange processes $(3,13)$. It was presumably these exchangers, located along the luminal membranes of colonic epithelial cells, that responded to the changes in $\mathrm{pHi}$ and intracellular $\mathrm{HCO}_{3}$ concentrations that mediated the $\mathrm{CO}_{2}$ effect (11).

In the present study, we examined the role of the various transport pathways by comparing the increments in ion flux caused by $\mathrm{CO}_{2}$ in the presence and absence of several transport

Table V. Effect of $\mathrm{CO}_{2}$ and Amiloride on Colonic Electrolyte Transport in Low Sodium Ringer's Solution

\begin{tabular}{|c|c|c|c|c|c|c|c|c|c|c|c|c|}
\hline \multirow[b]{2}{*}{ Addition } & \multirow[b]{2}{*}{$\mathrm{PCO}_{2}$} & \multirow[b]{2}{*}{$\mathrm{pH}$} & \multirow[b]{2}{*}{ Isc } & \multirow[b]{2}{*}{ PD } & \multirow[b]{2}{*}{ G } & \multicolumn{3}{|c|}{$\mathrm{Na}$ flux } & \multicolumn{3}{|c|}{ Cl flux } & \multirow[b]{2}{*}{$J^{\mathbf{R}}$} \\
\hline & & & & & & $J \mathrm{~ms}$ & Jsm & Jnet & $J \mathrm{~ms}$ & Jsm & Jnet & \\
\hline & $m M$ & & $\mu e q / \mathrm{cm}^{2}$ per $h$ & $m V$ & $\mathrm{mS} / \mathrm{cm}^{2}$ & \multicolumn{3}{|c|}{$\mu e q / \mathrm{cm}^{2}$ per $h$} & \multicolumn{3}{|c|}{$\mu e q / \mathrm{cm}^{2}$ per $h$} & \\
\hline \multirow[t]{4}{*}{ None } & 21.3 & 7.64 & 1.5 & 8.3 & 4.6 & 8.7 & 1.8 & 6.9 & 12.8 & 7.3 & 5.5 & 0.1 \\
\hline & \pm 0.6 & \pm 0.01 & \pm 0.3 & \pm 1.1 & \pm 0.6 & \pm 2.3 & \pm 0.4 & \pm 2.1 & \pm 1.8 & \pm 0.7 & \pm 1.3 & \pm 1.4 \\
\hline & 71.1 & 7.11 & 0.7 & 5.1 & 3.9 & 10.5 & 1.6 & 8.9 & 16.3 & 8.0 & 8.3 & 0.1 \\
\hline & \pm 0.3 & \pm 0.0 & \pm 0.1 & \pm 0.8 & \pm 0.6 & \pm 2.5 & \pm 0.3 & \pm 2.3 & \pm 2.2 & \pm 0.5 & \pm 2.0 & \pm 1.8 \\
\hline$P^{*}$ & $<0.001$ & $<0.001$ & $<0.02$ & $<0.001$ & $<0.02$ & $<0.005$ & & $<0.005$ & $<0.001$ & $<0.05$ & $<0.01$ & \\
\hline \multirow[t]{4}{*}{ Amiloride $(0.75 \mathrm{mM})$} & 21.3 & 7.64 & 1.2 & 6.8 & $4.1^{\ddagger}$ & $3.8^{\ddagger}$ & 1.7 & $2.1^{8}$ & $10.2^{\S}$ & 7.4 & $2.9^{8}$ & 1.9 \\
\hline & \pm 0.6 & \pm 0.01 & \pm 0.3 & \pm 0.9 & \pm 0.6 & \pm 0.8 & \pm 0.4 & \pm 0.6 & \pm 0.9 & \pm 0.7 & \pm 0.5 & \pm 0.5 \\
\hline & 71.1 & 7.11 & 0.5 & 3.4 & 3.7 & 3.9 & 1.4 & 2.4 & 12.9 & 8.4 & 4.5 & 2.8 \\
\hline & \pm 0.3 & \pm 0.0 & \pm 0.1 & \pm 0.6 & \pm 0.4 & \pm 0.9 & \pm 0.3 & \pm 0.7 & \pm 1.4 & \pm 0.7 & \pm 1.0 & \pm 0.8 \\
\hline$P^{*}$ & $<0.001$ & $<0.001$ & & $<0.01$ & & & & & $<0.01$ & $<0.05$ & $<0.05$ & \\
\hline
\end{tabular}

Values are means \pm SE. Number of tissue pairs studied $=7$. Tissue pairs were studied in $50 \mathrm{mM} \mathrm{Na}, 21 \mathrm{mM} \mathrm{HCO} \mathrm{Hinger}^{\prime}$ solution at $\mathrm{CO}_{2}$ tensions of 21.3 and $71.1 \mathrm{mmHg}$ in the presence and absence of $0.75 \mathrm{mM}$ luminal amiloride. ${ }^{*}$ Paired $t$ test. ${ }^{\ddagger} P<0.02,{ }^{8} P<0.05$ when compared with addition: none at $\mathrm{PCO}_{2}=21.3 \mathrm{mmHg}$ by paired $t$ test. 
inhibitors. This method allowed us to differentiate between the presence of a transport process and its participation in the colonic response to $\mathrm{CO}_{2}$ (12). The most dramatic example of such a dissociation was our finding that $0.1 \mathrm{mM}$ furosemide inhibited both sodium and chloride absorption $~ 55 \%$ at $\mathrm{PCO}_{2}$ $=21.6 \mathrm{mmHg}$, but did not reduce the increments in absorption caused by increasing the $\mathrm{PCO}_{2}$. We interpret this finding to mean that an electroneutral sodium chloride absorptive process inhibited by furosemide, although present in rat colonic epithelial cells and an important pathway for sodium absorption, does not respond to alterations in $\mathrm{PCO}_{2}$. It is not clear at present whether furosemide inhibited a sodium chloride absorptive process distinct from $\mathrm{Na} / \mathrm{H}$ and $\mathrm{Cl} / \mathrm{HCO}_{3}$ ion exchange, or whether these antiporters are sensitive to furosemide (but not $\mathrm{CO}_{2}$ ) under certain experimental and physiologic conditions. Indeed, in one recent study using apparently similar methodology, furosemide-sensitive sodium chloride absorption was not found in the rat distal colon (18).

We may compare the effects of furosemide on colonic absorption with those of luminal amiloride. At a $\mathrm{PCO}_{2}$ of 21.6 $\mathrm{mmHg}$, amiloride also markedly inhibited sodium absorption. In fact, at low $\mathrm{CO}_{2}$ tensions, the combination of amiloride and furosemide reduced net sodium and chloride absorption to zero. However, whereas $\mathrm{CO}_{2}$ and furosemide apparently affect separate sodium absorptive pathways, $\mathrm{CO}_{2}$ and amiloride modulate the same process. We found that the increment in net sodium absorption caused by an increase in $\mathrm{PCO}_{2}$ was markedly diminished in the presence of amiloride. At luminal bathing solution concentrations reported to inhibit $\mathrm{Na} / \mathrm{H}$ ion exchange in a variety of epithelia and membrane vesicle preparations (19-22), amiloride reduced the increment in sodium absorption $\sim 60 \%$. The presence of amiloride did not affect the increment in chloride absorption, but was associated with a $\mathrm{PCO}_{2}$-induced increase in $J^{\mathrm{R}}$ that was not observed in its absence. These findings suggest that both $\mathrm{Na} / \mathrm{H}$ and $\mathrm{Cl} / \mathrm{HCO}_{3}$ ion exchange processes are present in the colonic epithelium and respond to alterations in $\mathrm{PCO}_{2}$.

There are two difficulties with this interpretation of the data. First, amiloride did not completely prevent the $\mathrm{CO}_{2}$-induced increase in sodium absorption. One possible explanation was that a furosemide-inhibitable sodium absorptive process might have become sensitive to $\mathrm{CO}_{2}$ (or $\mathrm{pH}$ ) when $\mathrm{Na} / \mathrm{H}$ ion exchange was inhibited. We ruled out this possibility by finding that amiloride plus furosemide did not have a greater effect on $\mathrm{CO}_{2}$-induced changes in sodium absorption than amiloride alone (Table IV). Another explanation for the incomplete amiloride inhibition was methodological: perhaps the concentration of sodium in the bathing solution $(140 \mathrm{mM})$ interfered with amiloride-inhibition of $\mathrm{Na} / \mathrm{H}$ ion exchange $(19,22,23)$. We examined this possibility by substituting choline chloride for sodium chloride to lower the bathing solution sodium concentration to $50 \mathrm{mM}$. As a result of this change, amiloride completely prevented the $\mathrm{PCO}_{2}$-induced increase in net sodium absorption. This finding appears to confirm the suggestion that the only sodium absorptive process responsive to $\mathrm{CO}_{2}$ is $\mathrm{Na} / \mathrm{H}$ ion exchange. It also may account for the apparent absence of amiloride-inhibitable $\mathrm{Na} / \mathrm{H}$ ion exchange in other studies of rat distal colon in which a similar bathing solution sodium concentration of $140 \mathrm{mM}$ was used $(19,21$, 24, 25).

A second difficulty in concluding that both $\mathrm{Na} / \mathrm{H}$ and $\mathrm{Cl}$ / $\mathrm{HCO}_{3}$ ion exchange are responsive to $\mathrm{CO}_{2}$ is our finding that mucosal DIDS at 0.1 and $1 \mathrm{mM}$ did not inhibit $\mathrm{CO}_{2}$-induced increments in chloride absorption. DIDS and related disulfonic stilbenes are reported to inhibit anion exchange in intact intestinal epithelia and membrane vesicles $(26,27)$. In recent studies of the rat proximal and distal colon, however, $2 \mathrm{mM}$ mucosal DIDS and $1 \mathrm{mM}$ 4-acetamido-4'-isothiocyanatostilbene-2,2'-disulfonic acid did not alter $J_{\text {net }}^{\mathrm{Na}}, J_{\text {net }}^{\mathrm{C}}$, or Isc despite other evidence suggesting that anion exchange was present (18, 28). Similar observations have been made in rabbit ileum (29) and rabbit colon (30). Our results therefore do not absolutely exclude the participation of $\mathrm{Cl} / \mathrm{HCO}_{3}$ ion exchange in the rat distal colon's response to $\mathrm{CO}_{2}$. As suggested by others, DIDS may not be a sensitive probe for anion exchange under all experimental conditions.

A role for mucosal carbonic anhydrase activity was tested for in a similar way: by inhibiting the enzyme and stimulating absorption with $\mathrm{CO}_{2}$. In fact, acetazolamide markedly reduced the effect of $\mathrm{PCO}_{2}$ on sodium absorption. This effect of acetazolamide also was observed during the luminal perfusion of the distal colon in intact anesthetized rats (12). The concentration of acetazolamide required to significantly reduce sodium chloride absorption, however, was greater ( $1 \mathrm{mM})$ than the concentration required to inhibit the enzyme in broken cell preparations $(0.1 \mathrm{mM})(12,31)$. Such high concentrations are often needed to inhibit carbonic anhydrase activity in gastrointestinal tissues mounted in Ussing flux chambers $(4,18$, 32). This may reflect the moderate water and lipid solubility of acetazolamide and its limited diffusion into tissues (31). Nevertheless, in some tissues, these acetazolamide concentrations may affect ion transport by mechanisms other than carbonic anhydrase inhibition (31). Such nonspecific or toxic effects, however, have not been observed in the rat distal colon (12). The specific effect of carbonic anhydrase inhibition is to alter $\mathrm{pHi}$ and as a consequence, electrolyte transport $(5,12,31,33)$. This role for $\mathrm{pHi}$ in the colon was suggested in previous studies by the finding that mucosal pHi varied directly with changes in arterial $\mathrm{PCO}_{2}$ and inversely with changes in sodium absorption (11). In the present study, it is thus likely that acetazolamide blunted the effect of $\mathrm{PCO}_{2}$ on colonic absorption by altering the pHi response to $\mathrm{PCO}_{2}$.

Finally, it was noteworthy that the effect of the plasma $\mathrm{HCO}_{3}$ concentration on colonic net $\mathrm{HCO}_{3}$ secretion observed in vivo (3) was not found in the Ussing flux chamber. Only a slightly higher level of $J^{\mathrm{R}}$ was found at a bathing solution $\mathrm{HCO}_{3}$ concentration of $39 \mathrm{mM}(\mathrm{pH} \mathrm{7.65)}$ than at $11 \mathrm{mM}(\mathrm{pH}$ 7.14). Although $J^{R}$ may not always be a reliable measure of net $\mathrm{HCO}_{3}$ secretion $(4,29)$, in our study, $J^{\mathrm{R}}$ appeared to reflect $\mathrm{HCO}_{3}$ transport. For example, $J^{\mathrm{R}}$ increased in response to increases in $\mathrm{PCO}_{2}$ in the presence of either amiloride or acetazolamide, additions that would be expected to cause disproportionate responses in $\mathrm{Na} / \mathrm{H}$ and $\mathrm{Cl} / \mathrm{HCO}_{3}$ ion exchange. In addition, $J^{\mathrm{R}}$ was zero and did not respond to changes in $\mathrm{pH}$ in the absence of bathing solution $\mathrm{CO}_{2}$ and $\mathrm{HCO}_{3}$ (Hepes buffer). We believe the difference between the in vivo and in vitro findings may be due to the equivalent $\mathrm{HCO}_{3}$ concentrations in the mucosal and serosal solutions in the chamber, and the differing $\mathrm{HCO}_{3}$ concentrations in the plasma and luminal perfusate in vivo. The in vivo results thus may have reflected the effect of a transmucosal $\mathrm{HCO}_{3}$ concentration gradient on intercellular $\mathrm{HCO}_{3}$ movement. It is also likely that the relatively large chamber volume and unpaired design of the $\mathrm{HCO}_{3}$ experiments limited our ability to detect small changes in net 
$\mathrm{HCO}_{3}$ secretion. This is especially relevant in light of the recent finding, using a new in vitro technique, that extracellular $\mathrm{HCO}_{3}$ concentration apparently does modulate active colonic $\mathrm{HCO}_{3}$ secretion $(9,34)$. For these reasons, our conclusions regarding the effects of $\mathrm{HCO}_{3}$ concentration and various inhibitors on $J^{\mathrm{R}}$ and $\mathrm{HCO}_{3}$ secretion by the colon must be tentative.

In summary, these studies establish a primary role for $\mathrm{CO}_{2}$ in regulating active sodium chloride absorption by the rat distal colon. The transport pathways stimulated by increasing $\mathrm{PCO}_{2}$ appear to be $\mathrm{Na} / \mathrm{H}$ and $\mathrm{Cl} / \mathrm{HCO}_{3}$ ion exchange processes located along the luminal border of colonic epithelial cells. This effect of $\mathrm{CO}_{2}$ requires mucosal carbonic anhydrase activity to generate the pHi change that mediates the observed changes in electrolyte transport. In general, these findings confirm previous observations, although a separate effect of extracellular $\mathrm{HCO}_{3}$ concentration on active colonic $\mathrm{HCO}_{3}$ secretion was not found.

\section{Acknowledgments}

The authors appreciate the technical assistance of Peter M. Ingrassia, the helpful advice of Dr. John I. Scheide, and the secretarial assistance of Elaine M. Allard.

This study was supported by the Veterans Administration.

\section{References}

1. Feldman, G. M., and A. N. Charney. 1980. Effect of acute metabolic alkalosis and acidosis on intestinal electrolyte transport in vivo. Am. J. Physiol. 239:G427-G436.

2. Feldman, G. M., and A. N. Charney. 1982. Effect of acute respiratory alkalosis and acidosis on intestinal electrolyte transport in vivo. Am. J. Physiol. 242:G436-G492.

3. Charney, A. N., and L. P. Haskell. 1984. Relative effects of systemic $\mathrm{pH}, \mathrm{PCO}_{2}$, and $\mathrm{HCO}_{3}$ concentration on colonic ion transport. Am. J. Physiol. 246:G159-G165.

4. Binder, H. J., and C. L. Rawlins. 1973. Electrolyte transport across isolated large intestinal mucosa. Am. J. Physiol. 225:12321239.

5. Phillips, S. F., and P. F. Schmalz. 1970. Bicarbanate secretion by the rat colon: effect of intraluminal chloride and acetazolamide. Proc. Soc. Exp. Biol. Med. 135:116-122.

6. Will, P. C., J. L. Lebowitz, and U. Hopfer. 1980. Induction of amiloride-sensitive sodium transport in the rat colon by mineralocorticoids. Am. J. Physiol. 238(Renal Fluid Electrolyte Physiol. 7):F261F268.

7. Yau, W. M., and G. M. Makhlouf. 1975. Comparison of transport mechanisms in isolated ascending and descending rat colon. Am. J. Physiol. 228:191-195.

8. Foster, E. S., T. W. Zimmerman, J. P. Hayslett, and H. J. Binder. 1983. Corticosteroid alteration of active electrolyte transport in rat distal colon. Am. J. Physiol. 245(Gastrointest. Liver Physiol. 8):G668G675.

9. Jorkasky, D., M. Cox, and G. M. Feldman. 1985. Differential effects of corticosteroids on $\mathrm{Na}^{+}$transport in rat distal colon in vitro. Am. J. Physiol. 248(Gastrointest. Liver Physiol. 11):G424-G431.

10. Kurtin, P.; and"A. N. Charney. 1984. Intestinal ịon transport and intracellular $\mathrm{pH}$ during acute respiratory alkalosis and acidosis. Am. J. Physiol. 247(Gastrointest. Liver Physiol. 10):G24-G31.

11. Wagner, J. D., P. Kurtin, and A. N. Charney. 1985. Effect of systemic acid-base disorders on colonic intracellular $\mathrm{pH}$ and ion transport. Am. J. Physiol. 249(Gastrointest. Liver Physibl. 12):G39-G47.

12. Charney, A. N., J.. D. Wagner, G. J. Birnbaum, and J. N. Johnstone. 1986. Functional role of carbonic anhydrase in intestinal electrolyte transport. Am. J. Physiol. 251(Gastrointest. Liver Physiol. 14):G682-G687.
13. Kurtin, P., and A. N. Charney. 1984. Effect of arterial carbon dioxide tension on amiloride-sensitive sodium absorption in the colon. Am. J. Physiol. 247(Gastrointest. Liver Physiol. 10):G537-G541.

14. Siggard-Andersen, O. 1974. The Acid-Base Status of the Blood. 4th ed. Williams \& Wilkins, Baltimore, MD. 30-34.

15. Snedecor, G. W.; and W. G. Cochran. 1967. Statistical Methods. 6th ed. Iowa State University Press, Ames, Iowa.

16. Frizzell, R. A., M. J. Koch, and S. G. Schultz. 1976. Ion transport by rabbit colon. I. Active and passive components. J. Membr. Biol. 27:297-316.

17. Charney, A. N., M. Arnold, and N. Johnstone. 1983. Acute respiratory alkalosis and acidosis and rabbit intestinal ion transport in vivo. Am. J. Physiol. 244(Gastrointest. Liver Physiol. 7):G145-G150.

18. Binder, H. J., E. S. Foster, M. E. Budinger, and J. P. Hayslett. 1987. Mechanism of electroneutral sodium chloride absorption in distal colon of the rat. Gastroentrology. 93:449-455.

19. Benos, D. J. 1982. Amiloride: a molecular probe of sodium transport in tissues and cells. Am. J. Physiol. 242(Cell Physiol. 11):C131-C145.

20. Foster, E. S., P. K. Dudeja, and T. A. Brasitus. 1986. $\mathrm{Na}^{+}-\mathrm{H}^{+}$ exchange in rat colonic brush-border membrane vesicles. Am. J. Physiol. 250(Gastrointest. Liver Physiol. 13):G781-G787.

21. Kinsella, J. L., and P. S. Aronson. 1981. Amiloride inhibition of the $\mathrm{Na}^{+}-\mathrm{H}^{+}$exchanger in renal microvillus membrane vesicles. Am. J. Physiol. 241(Renal Fluid Electrolyte Phyșiol. 10):F374-F379.

22. Grinstein, S., and A. Rothstein. 1986. Mechanisms of regulation of the $\mathrm{Na}^{+} / \mathrm{H}^{+}$exchanger. J. Membr. Biol. 90:1-12.

23. Turnheim, K., R. A. Frizzel, and S. G. Schultz. 1978. Interaction between cell sodium and the amiloride-sensitive sodium entry step in rabbit colon. J. Membr. Biol. 39:233-256.

24. Budinger, M. D., E. S. Foster, J. P. Hayslett, and H. J. Binder. 1986. Sodium and chloride transport in the large intestine of potassium-loaded rats. Am. J. Physiol. 251(Gastrointest. Liver Physiol. 14):G249-G252.

25. Halevy, J., M. E. Budinger, J. P. Hayslett, and H. J. Binder. 1986. Role of aldosterone in the regulation of sodium and chloride transport in the distal colon of sodium-depleted rats. Gastroenterology. 91:1227-1233.

26. Hatch, M., R. W. Freel, A. M. Goldner, and D. L. Earnest. 1984. Oxalate and chloride absorption by the rabbit colon: sensitivity to metabolic and anion transport inhibitors. Gut. 25:232-237.

27. Knickelbein, R., P. S. Aronson, C. M. Schron, J. Seifter, and J. W. Dobbins. 1985. Sodium and chloride transport across rabbit ileal brush border. II. Evidence for $\mathrm{Cl}-\mathrm{HCO}_{3}$ exchange and mechanism of coupling. Am. J. Physiol. 249(Gastrointest. Liver Physiol. 12):G236G245.

28. Foster, E. S., M. E. Budinger, J. P. Hayslett, and H. J. Binder. 1986. Ion transport in proximal colon of the rat. J. Clin. Invest. 77:228-235.

29. Smith, P. L., M. A. Cascairo, and S. K. Sullivan. 1985. Sodium dependence of luminal alkalinization by rabbit ileal mucosa. Am. $J$. Physiol. 249(Gastrointest. Liver Physiol. 12):G258-G268.

30. Langridge-Smith, J. E., and M. Field. 1981. Sulfate transport in rabbit ileum: characterization of the serosal border anion exchange process. J. Membr. Biol. 63:207-214.

31. Maren, T. H. 1977. Use of inhibitors in physiological studies of carbonic anhydrase. Am. J. Physiol. 232 (Renal Fluid Electrolyte Physiol. 4):F291-F297.

32. Nellans, H. N., R. A. Frizzell, and S. G. Schultz. 1975. Effect of acetazolamide on sodium and chloride transport by in vitro rabbit ileum. Am. J. Physiol. 228: 1808-1814.

33. Jones, B., and D. P. Simpson. 1983. Influence of alterations in acid-base conditions on intracellular $\mathrm{pH}$ of intact renal cortex. Renal Physiol. 6:28-35.

34. Feldman, G. M., S. F. Berman, and R. L. Stephenson. 1988. Bicarbonate secretion in rat distal colon in vitro: a measurement technique. Am. J. Physiol. 254 (Cell Physiol. 23): C383-C390. 